\title{
The Best of Both Worlds? Some Reflections on the interaction between the Common Law and the Bill of Rights in our new Constitution ${ }^{*}$
}

Kate O'Regan. Judge of the Constitutional Court.

\section{Introduction}

We live in an extraordinary society blessed with an extraordinary legal system. It is now widely accepted that ours is a mixed or hybrid legal system, which draws both on civilian and common-law traditions. We are also a legally pluralistic society in which several systems of law, particularly personal law, co-exist. In the academy, the systems of African customary law and Muslim personal law, have until recently only enjoyed a half-life. In the past, when we taught the law of succession or family law, we generally taught only the Roman-Dutch common law system and not customary law rules of succession under African tradition or Muslim practice. Students who wished to study African customary law or Muslim personal law had to take special courses in those areas of law, and in many universities those courses were optional and not regarded as core knowledge required by lawyers. This despite the fact that in reality a very significant proportion of South Africans are married according to legal systems whose rules are not Roman Dutch in origin.

The lack of interest in African customary law (and muslim law) needs to be understood in the context of our apartheid past and the response of the legal academy and profession to apartheid. In general, law as an academic subject and as bread and butter for the legal profession was that law that governed the lives of white South Africans. Which is why most law students graduating in the 1960's and 1970's, and even in the 1980's, could leave the law school with a sophisticated understanding of the principles of wrongfulness in delict, the stipulatio alteri, the question of animo injuriandi, the praetor's edicts and a host of other important technical principles of

Paper delivered at the second Colloquium Constitution and Law held at Potchefstroom on 30 October 1998. This paper was first published by the Konrad-Adenauer-Stiftung in their Seminar Report of the Colloquium (Johannesburg 1999). 
law, but with no knowledge of section 10 of the Black (Urban Areas) Consolidation Act 1945, or the Black Land Act 1913, the Black Administration Act 1927 or the rules of matrimonial property in customary law.

We are concerned today with the relationship between the Bill of Rights in our new Constitution and the common law. It seems to me that the time has come for us to embrace within our understanding of South African common law - not only our Roman-Dutch heritage, but also the English law heritage which is so profound in many areas of our law, and also the legal pluralism which is a reality in our legal system particularly in the areas of family law and the law of persons. We need to move away from the distinctions of the past which considered common law as only Roman Dutch law and move towards a more inclusive conception of common law which reflects the wide variety of legal sources and traditions which make up in reality our common law. In my discussion this morning I will speak of the common law in this more inclusive manner.

In this presentation, I intend to start by considering some of the key characteristics of the common law which I think are relevant for our discussion. Then I will identify key aspects of the Constitution similarly relevant and then consider the ways in which the common law and the Constitution are likely to interact.

\section{The chief characteristics of our hybrid system of common law}

It seems to me that for the purpose of our discussion this morning it may be helpful to identify the chief characteristics of our hybrid system of common law as the following:

- It is not a codified system. Although in some areas, statutes have been introduced to replace or codify aspects of our common law, generally large areas of the law of property, contract, delict, trusts, unjustified enrichment, criminal law, administrative law and to a lesser extent family law remain governed directly and purely by common law. The relevant rules are therefore rules developed by a traditional common law system through case law and precedent. 
- The common law is a living and organic system of law which is constantly under review by both the legislature and judges. The legislature intervenes quite frequently in areas of the common law to alter common law rules. For example, far-reaching changes to family law were affected by the Divorce Act 1979, the Matrimonial Property Act 1984 and the Matrimonial Property Act 1988. Similarly, judges are in a position to develop and modify rules of the common law to the extent that is necessary. During the 1970s in particular significant changes to the rules governing aquilian liability were introduced through a series of judgments of the Appellate Division. ${ }^{1}$ Perhaps the most significant aspect of the development of aquilian liability in the 1970s lay in the jurisprudential approach which characterised the developments. Corbett CJ identified this approach in the following way:

Even in 1975 there were probably still two choices open to the court in the Ewels case. The one was to confine liability for an omission to certain stereotypes, possibly adding to them from time to time; the other was to adopt a wider, more open-ended general principle, which, while comprehending existing grounds of liability would lay the foundation for a more flexible and all-embracing approach to the question whether a person's omission to act should be held unlawful or not. The court made the latter choice; and, of course, in doing so cast for the courts a general policymaking role in this area of the law. ${ }^{2}$

The development of the rules governing liability for omissions in Ewels' case, led shortly to the extension of liability for emotional shock in Bester's case and to liability for negligent misstatements in Administrateur, Natal v Trust Bank. This development of aquilian liability is an example of how vigorous and principled development of the common law can be. The development arises in response to a need identified by the

1 See, for example, Minister van Polisie v Ewels 19753 SA 590 (A) aquilian liability will arise from omission in certain circumstances; Administrateur, Natal v Trust Bank van Afrika Bpk 1979 3 SA 824 (A) extension of aquilian liability to economic loss arising from negligent misstatements; Bester v Commercial Union Versekeringsmaatskappy van Suid Afrika Bpk 19731 SA 768 (A) emotional shock will give rise to a claim for aquilian damages.

2 Corbett $S A L J$ at 56. 
court. Innes CJ encapsulated the judicial philosophy underlying the development of the common law in Blower $v$ Van Norden: ${ }^{3}$

There come times in the growth of every living system of law when old practice and ancient formulae must be modified in order to keep in touch with the expansion of legal ideas, and to keep pace with the requirements of changing conditions. And it is for the Courts to decide when the modifications, which time has proved to be desirable, are of a nature to be effected by judicial decision, and when they are so important or so radical that they should be left to the Legislature.

- The rules of common law are based on a rich variety of sources. First, of course, is the body of South African case law stretching back to the establishment of the Supreme Court at the Cape of Good Hope by the Charter of Justice in 1828. Almost immediately from its inception, the Supreme Court relied on the doctrine of precedent ${ }^{4}$ and a strict system of precedent operates still. ${ }^{5}$ Singularly important to the development of a doctrine of precedent has been, of course, the publication of law reports - something which many other African countries do not have. A second important source of law, of course, are the civil law authorities which predate the era of codification in Europe. There is some debate as to which civil law writers may be considered but although there are dicta which suggest that only authorities writing of the law of Holland in the seventeenth and eighteenth centuries should be considered, ${ }^{6}$ the courts have often drawn on writers outside that narrow circle. Where there is dispute amongst the writers, the courts have held that they may...

3 Blower $v$ Van Norden 1909 TS 890 at 905

4 See Zimmerman and Visser Introduction at 15. The authors comment that as early as 1830 the Cape of Good Hope Supreme Court was citing its own authority.

5 For a full account of the system of precedent, see Hahlo and Kahn Legal System chapter 7.

6 See Van den Heever JA in Tjollo Ateljees (Edms) Bpk v Small 19491 SA 856 (A) at 865; and also Corbett JA in Du Plessis v Strauss 19882 SA 105 (A) at 149. See for a full discussion Fagan Roman-Dutch Law; also Visser THRHR. 
..."choose to rely upon those opinions which appear to us to be more conformable to reason" (and, I would add, more in conformance with the law and requirements of our time). ${ }^{7}$

The influence of civilian law authorities is greater in some areas of the law than others and is particularly strong in the areas of delict, property, contract, family law and unjust enrichment. I would suggest, however, that to label our common law "RomanDutch" is no longer accurate. Much of our common law draws from English authorities. So, for example, in 1979 when Cameron and Van Zyl Smit made a headcount of the law reports, they found 193 references to English and Privy Council decisions, 21 to Commonwealth judgments and 11 to American judgments. These references came in 99 of the 684 reported cases (almost 1 in 7). On the other hand they found references to Roman or Roman Dutch materials in only 39 of the reported cases. $^{8} \quad$ As this survey suggests, in some areas, particularly those where statutory provisions have been enacted based on English models, English case law, although never binding, of course, has significant persuasive value. Areas where English law has proved to be of particular importance include intellectual property, insurance law, administrative law, bills of exchange and company law. In many of these areas of law, one would search in vain for any reference to civilian law authorities. In the case of family law, in particular, many South African marriages are governed by rules of customary or Muslim personal law. There are a range of sources of customary law and Muslim personal law. In addition, such marriages are recognised for some purposes and not for others. Professor DP Visser has suggested that the rich variety of sources which are available to our common law are a source of concern because they deprive our law of consistency and coherence. ${ }^{9}$ Although I agree with him that our common law does have a rich variety of sources to draw from, I am not at all persuaded that that is a weakness of our system. It may indeed be its great strength.

7 Hefer JA in Willis Faber Enthoven (Pty) Ltd v Receiver of Revenue 19924 SA 202 (A) at 219I-J citing Van den Heever JA in Tjollo Ateljees (Edms) Bpk v Small 19491 SA 856 (A), at 874.

8 See Cameron and Van Zyl Smit Annual Survey 538 ff. Professor Visser states that when he did a similar count in 1985, similar figures were produced. See Visser THRHR. It would be interesting to see what the product of a similar exercise recently would produce particularly in the light of the constitutional provision permitting courts to consider foreign law when interpreting the Bill of Rights (section 39(1)(c)). 
- The style of litigation and adjudication is English rather than Continental in character. Rules of procedure were originally modelled on English rules, though some non-English procedures exist - for example provisional sentence and the mandament van spolie. The style of judgments is English or Anglo-American as well. Professors Zimmerman and Visser however have suggested that the willingness of South African courts to cite and rely on academic commentators is a feature more familiar to Continental jurisdictions. ${ }^{10}$ It is true that reliance on academic writing is rare in English judgments, but that is considerably less true of both North American and Australian jurisdictions. There can be no doubt however that South African judgments do often cite extensively from academic writing and that academic writing remains an influential resource in South African law.

- When a common law rule is modified or altered, it is retrospectively altered. For example when the Appellate Division decided in Willis Faber Enthoven (Pty) Ltd $v$ Receiver of Revenue ${ }^{11}$ that an excusable mistake of law should be no bar to the condictio indebiti (as had formerly been the case ${ }^{12}$ ), it ordered repayment of the funds it found to have been paid pursuant to an excusable mistake of law. The effect of such a retrospective alteration means of course that the litigant who has sought the relief before the court, is granted such relief. If the court were to alter the law prospectively only, it may result in litigants who have in fact generated the development of the common law not receiving relief. The principle of retrospective alteration is in conflict with principles of legal certainty.

\section{The chief constitutional provisions}

I turn now to the Constitution and turn to look at some of its key provisions in the context of our consideration of the relationship between the Constitution and the common law. Section 2 of the Constitution contains the supremacy clause which provides that the Constitution is the supreme law of the Republic and that law or

9 See Visser THRHR at 136-137.

10 See Zimmerman and Visser Introduction 11.

11 Willis Faber Enthoven (Pty) Ltd v Receiver of Revenue 19924 SA 202 (A) 
conduct inconsistent with it is invalid. It also provides that obligations imposed by the Constitution must be fulfilled.

In one of its early decisions, the Constitutional Court held that the effect of the supremacy clause was that legislation inconsistent with it was "objectively invalid". Therefore when the Constitutional Court finds that a piece of legislation is inconsistent with the Constitution, that inconsistency has conceptually existed since the date the Constitution came into force (in the case of legislation that predates the Constitution) or the date on which the legislation was enacted (in the case of legislation enacted since the Constitution came into force). ${ }^{13}$ The implications of objective invalidity for a rule of the common law are, therefore, that where a rule of the common law is in conflict with the Constitution it is invalid from the date of the Constitution unless the Court makes some other finding.

It is clear that whether a legislative provision, whether it be a provision in an Act of Parliament passed by the national legislature, or a piece of provincial legislation, or a municipal by-law, or a regulation or piece of subordinate legislation, will be invalid to the extent that it is in conflict with the Constitution. Courts have no discretion to refuse to declare such legislative provisions invalid as section 172(1) makes clear. However they are given wide and flexible powers to make an order that is in accordance with justice and equity. These include powers to limit retrospectivity and to suspend orders of invalidity conditionally.

Section 172 provides:

(1) When deciding a constitutional matter within its power, a court -

(a) must declare that any law or conduct that is inconsistent with the Constitution is invalid to the extent of its inconsistency;

(b) may make any order that is just and equitable, including -

(i) an order limiting the retrospective effect of the declaration of invalidity; and

12 See Rooth $v$ The State (1888) 2 SAR 259.

13 See Ferreira v Levin; Vryenhoek v Powell 19961 SA 984 (CC); 1996 (1) BCLR 1 (CC). 
(ii) an order suspending the declaration of invalidity for any period and on any conditions, to allow the competent authority to correct the defect.

Recently, the Constitutional Court had an opportunity to consider the scope of the power conferred by section 172 (1)(b) when it declared the common law offence of sodomy to be inconsistent with the Constitution in National Coalition for Gay and Lesbian Equality $v$ Minister of Justice. ${ }^{14}$ Ackermann $\mathrm{J}$ held that the requirements of justice and equity contained in section 172 are broader and more flexible than the equivalent provisions of section 98(6) and 98(7) of the interim Constitution where the court was given powers to act in the interests of justice and good government.

In addition to the powers under section 172, however, courts are given the power to develop the common law. Section 173 of the Constitution provides:

The Constitutional Court, Supreme Court of Appeal and High Courts have the inherent power to protect and regulate their own process, and to develop the common law, taking into account the interests of justice.

It is clear from this provision that all courts have the power to develop the common law. Clearly, as the Constitutional Court only has jurisdiction over constitutional matters and issues connected with decisions on constitutional matters (section 167(3)(b)), it will only have the power to develop the common law in circumstances where that development is a constitutional matter or an issue connected with a decision on a constitutional matter. It is clear that in some circumstances, it will be necessary to exercise this power to make an order that is just and equitable as required by section 172(1)(b).

The Constitution clearly binds all lawmaking agencies in South Africa. It also binds the executive. And in certain circumstances, yet to be fully explored, it binds private individuals and corporations. Section 8 of the Constitution provides as follows:

14 CCT 11/98 as yet unreported decision dated 9 October 1998. 
(1) The Bill of Rights applies to all law, and binds the legislature, the executive, the judiciary and all organs of state.

(2) A provision of the Bill of Rights binds a natural or a juristic person if, and to the extent that, it is applicable, taking into account the nature of the right and the nature of any duty imposed by the right.

When the court finds that a natural or juristic person is bound by a provision of the Bill of Rights, section 8(3) provides as follows:

(3) When applying a provision of the Bill of Rights to a natural or juristic person in terms of subsection (2), a court -

(a) in order to give effect to a right in the Bill, must apply, or if necessary develop, the common law to the extent that legislation does not give effect to that right; and

(b) may develop rules of the common law to limit the right, provided that the limitation is in accordance with section 36(1).

The Constitution clearly envisages two forms of constitutional normative effect: the first is the direct application of the Constitution to principles of law as envisaged both by section 2 and section 8(1). Where a rule of law is in breach of the Constitution in such circumstances, section 172 (read with section 2) makes it plain that such rule is invalid, and must be declared so. The second type of normative effect is what the Germans called Mittelbare or indirect normative effect. It is clearly envisaged by section 39(2) which provides that interpreting statutes and developing the common law and customary law, a court shall promote the spirit, purport and objects of the Bill of Rights.

(1) When interpreting the Bill of Rights, a court, tribunal or forum -

(a) must promote the values that underlie an open and democratic society based on human dignity, equality and freedom;

(b) must consider international law;

(c) may consider foreign law. 
(2) When interpreting any legislation, and when developing the common law or customary law, every court, tribunal or forum must promote the spirit, purport and objects of the Bill of Rights.

(3) The Bill of Rights does not deny the existence of any other right or freedoms that are recognised or conferred by common law, customary law or legislation to the extent that they are consistent with the Bill.

Section 39(2) gives express constitutional recognition therefore to our accepted and recognised mode of development of the common law. It makes it clear that the spirit, purport and objects of the Bill of Rights should guide that development, but beyond giving a clear constitutional and normative basis to such development permits the longstanding traditions of our common law to continue.

\section{Areas of interaction between the common law and the Constitution}

There are two areas of interaction between the common law and the Constitution which I would like to explore in the rest of my address this morning. The first relates to the question of the situation where a rule of the common law is in conflict, or potential conflict, with the Constitution. In relation to this area, as I have said above, the Constitution clearly envisages two ways in which the Constitution's normative impact may be resolved. The first is by direct application of the provisions of the Constitution to a rule of the common law in circumstances where the Constitution is applicable and the second is by the development of the common law in a manner which is consistent with the spirit, purport and objects of the Constitution. The second area in which there is likely to be considerable interaction between the common law and the Bill of Rights relates to situations where the common law already provides some or complete protection for the rights provided by the Bill of Rights. I will return to this issue after I have considered the first area.

There are already suggestions in the case law that the spirit, purport and objects of the Bill of Rights are alive and well in recent common law discourse. For example, in $S v$ 
$J^{15}$, the Supreme Court of Appeal held that the cautionary rule that had previously applied to the evidence of a complainant in cases concerning sexual assault was -

... based on an irrational and out-dated perception. It unjustly stereotypes complainants in sexual assault cases (overwhelmingly women) as particularly unreliable. In our system of law, the burden is on the State to prove the guilt of an accused beyond reasonable doubt - no more and no less. The evidence in a particular case may call for a cautionary approach, but that is a far cry from the application of a general cautionary rule. ${ }^{16}$

This landmark judgment made no mention of the Constitution or section 39(2). There can be little doubt however that the clear concern it manifests for the implications of sexual violence for gender equality echo the concerns of the Constitution. Rejecting the proposition that it is easy to cry rape, Olivier JA reasoned as follows:

Few things may be more difficult and humiliating for a woman than to cry rape; she is often, within certain communities, considered to have lost her credibility; she may be seen as unchaste and unworthy of respect; her community may turn its back on her; she has to undergo the most harrowing cross-examination in court, where the intimate details of the crime are traversed ad nauseam; she (but not the accused) may be required to reveal her previous sexual history; she may disqualify herself in the marriage market, and many husbands turn their backs on a "soiled" wife. ${ }^{17}$

Similarly in National Media Ltd $v$ Bogoshi ${ }^{18}$ the Supreme Court of Appeal recast certain principles in the law of defamation, that have been the subject of much debate and judicial consideration in recent years. Indeed it was this very aspect of law which founded the litigation in Du Plessis $v$ De Klerk ${ }^{19}$ and Gardener $v$ Whitaker. ${ }^{20}$ Hefer

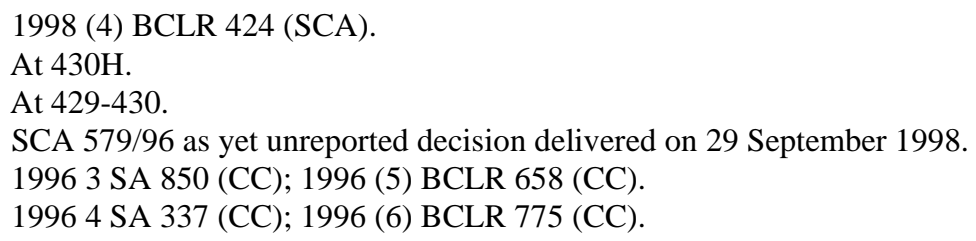


JA (writing for a unanimous court) held that the principle of strict liability for the media established in Pakendorf $v$ De Flaming ${ }^{21}$ needed to be rejected:

If we recognise, as we must, the democratic imperative that the common good is best served by the free flow of information and the task of the media in the process, it must be clear that strict liability cannot be defended and should have been rejected in Pakendorf. Much has been written about the "chilling" effect of defamation actions but nothing can be more chilling than the prospect of being mulcted in damages for even the slightest error. ${ }^{22}$

Although the press are no longer strictly liable, the judge held that the onus was on the press to establish absence of negligence where they had published defamatory matter. In addition, the judge went on to establish a defence to unlawfulness of reasonableness (in respect of which the onus would also lie on defendants) in the following terms:

In my judgment we must adopt this approach by stating that the publication in the press of false defamatory allegations of fact will not be regarded as unlawful if, upon a consideration of all the circumstances of the case, it is found to have been reasonable to publish the particular facts in the particular way and at the particular time.

In considering the reasonableness of the publication account must obviously be taken of the nature, extent and tone of the allegations. We know, for instance, that greater latitude is usually allowed in respect of political discussion. $^{23}$

He observed further that "[p]roof of reasonableness will usually (if not inevitably) be proof of lack of negligence." 24

2119823 SA 146 (A).

22 At 25-26 of the printed judgment.

23 At 30-31 of the printed judgment.

24 At 39. 
Having developed the common law in this way, the judge then turned to consider whether the approach he had adopted was one which accorded with the spirit, purport and objects of the Constitution and concluded that it was. These two decisions are in my view striking examples of the way that techniques of the common law may be used to develop the common law within the normative framework of the Constitution. They are by no means isolated examples of such jurisprudence. The law reports bristle with such examples.

In addition to this technique of developing the common law, it is clear from existing constitutional jurisprudence that at least in some cases the common law may be directly challenged under the Constitution. The first case in which this occurred was Shabalala $v$ Attorney-General, Transvaal ${ }^{25}$ in which the ruling of the Appellate Division in $R v$ Steyn $^{26}$ was challenged as unconstitutional. Steyn's case had held that the prosecution enjoyed a privilege in relation to the contents of a police docket so that the accused could be denied access to witness statements and other material in the docket. The Constitutional Court held that this "blanket docket privilege" rule was inconsistent with the Constitution to the extent that it protected from disclosure all the documents in a police docket regardless of whether disclosure was justified to enable the accused to prepare to exercise his or her right to a fair trial. More recently, in the National Coalition for Gay and Lesbian Equality case (referred to above) the Constitutional Court held that the common law crime of sodomy was inconsistent with the Constitution and declared it invalid.

Where provisions of the common law or customary law that conflict with provisions of the Bill of Rights are developed in the light of the spirit, purport and objects of the Bill of Rights in such a way that they are no longer in conflict with the Constitution, no need for a direct challenge will remain as the Constitutional Court recognised in Amod v Multilateral Motor Vehicle Accidents Fund. ${ }^{27}$

2519961 SA 725 (CC); 1995 (12) BCLR 1593 (CC).

261954 (1) SA 324 (A).

271998 (10) BCLR 1207 (CC) [26]. 
Some interesting questions arise, however, where the development of the common law is used as the mechanism for harmonisation of the common law with the Constitution rather than the direct challenge. Two of these questions concern retrospectivity. As Kentridge AJ mentioned in Du Plessis v De Klerk ${ }^{28}$, the common law and the Constitution regulate retrospectivity potentially differently. Two different questions arise - the question concerning whether the Constitution may apply to conduct which was completed before the Constitution came into force and the question of whether a court may limit the retrospective effect of a finding of constitutional invalidity. The Constitutional Court has held repeatedly that the rights entrenched in the interim and 1996 Constitutions have no general application in respect of conduct completed before the constitutions came into force. ${ }^{29}$ If the common law is developed to give effect to the spirit, purport and objects of the Constitution, it may or may not limit that development to conduct which took place after the Constitution came into force. This is an issue which crisply raised by the facts of Amod's case which now may be heard by the Supreme Court of Appeal.

The second question is whether the retrospective effect of a declaration of invalidity may be limited. Section 98(6) of the interim Constitution and section 172(1)(b) of the 1996 Constitution permit a court invalidating a law to limit the retrospective operation of that declaration of invalidity. However, this is not generally a practice of our courts or of other common law courts, as Kentridge AJ observed in Du Plessis' case, and as I have observed earlier. However in the United States of America, the courts have developed principles which permit limited retrospective effect for their rulings.

This question leads to the further question of the relative remedial powers of a court when harmonisation is achieved through development of the common law, on the one hand, or through the direct application of the Constitution on the other. Where the Constitution is directly applicable and a finding of invalidity is made, then it is clear that the courts will have the powers granted to them by sections 172 and 173 . Where however the court achieves harmonisation through the development of the common

2819963 SA 850 (CC); 1996 (5) BCLR 658 (CC) at [65] and [66].

29 See, e.g. S v Mhlungu 19953 SA 867 (CC); 1995 (7) BCLR 793 (CC); Du Plessis v De Klerk cited above. 
law, it is not clear at this stage what precise powers a court will have. In Amod's case, these issues were specifically left open by the Constitutional Court.

The second area in which there is likely to be considerable interaction between the common law and the Bill of Rights relates to the rights provided by the Bill of Rights. It is clear from the Constitution that the Constitution intends a remedy for the rights entrenched, and the Court has held this on several occasions, most recently in Fedsure Life Assurance Ltd v Greater Johannesburg Transitional Metropolitcan Council. ${ }^{30}$ In that case we were concerned with the application of section 24 of the interim Constitution, the right to administrative justice. In the joint judgment of Chaskalson $\mathrm{P}$, Goldstone $\mathrm{J}$ and myself (which on this point was concurred by all sitting members of the court), the court held:

In the circumstances, there can be no doubt, as implicit in the formulation of the question, that persons denied lawfully or procedurally fair administrative action can look to the court to enforce rights vested in them by section 24, and that in terms of the constitution this Court is the court of final instance in respect of any such dispute. Whether the direct application of the provisions of section 24 of the interim Constitution means that the common law must meet the requirements of the section, or that the section grounds a cause of action independent of the common law need not be decided. ${ }^{31}$

There many areas of the Bill of Rights where no common law remedy exists at present - for example one can consider the equality clause. Generally there is no existing cause of action recognised by common law that would provide one with a remedy for a breach of the equality clause and it is clear therefore that a plaintiff may rely directly on section 8 to establish an independent cause of action itself.

30 CCT 7/98 as yet unreported judgment 14 October 1998.

31 Fedsure Life Assurance Ltd v Greater Johannesburg Transitional Metropolitcan Council CCT $7 / 98$ [105]. 
However, there are other areas of the Bill of Rights where the right protected by the Constitution may be remedied by an existing common law remedy whether with or without adaptation. An example of this is in the area of administrative justice.

Section 24(a) and (b) of the interim Constitution entrench everyone's right to lawful administrative action (where any of his or her rights or interests is affected or threatened) and to procedurally fair administrative action (where any of his or her rights or legitimate expectations is affected or threatened). Although the common law has never been formulated so crisply, there can be no doubt that there is a correspondence between these rights and the rights generally afforded by our administrative law. The question that arises is whether if the common law is adequate or may be adequate with development does the Constitution nevertheless ground an independent cause of action. The court specifically left open this question in Fedsure in the passage which I have just cited. There is conflicting case law in the High Court on this question particularly in relation to section 24. In answering the question attention must be paid to the provisions of section 38 of the Constitution which provides as follows:

Anyone listed in this section has the right to approach a competent court alleging that a right in the Bill of Rights has been infringed or threatened, and the court may grant appropriate relief, including a declaration of rights. The persons who may approach a court are -

(a) anyone acting in their own interest;

(b) anyone acting on behalf of another person who cannot act in their own name;

(c) anyone acting as a member of, or in the interest of, a group or class of persons;

(d) anyone acting in the public interest; and

(e) an association acting in the interest of its members.

The question of a multiplicity of causes of action arising from the same pattern of conduct arises in relation to other rights as well. For example, in Fose v Minister of 
Safety and Security ${ }^{32}$ the Court was concerned with an exception to a claim for damages arising out of the alleged torturing of the plaintiff by policemen. The plaintiff had sought damages for patrimonial loss and contumelia, and sought in addition constitutional damages including punitive damages. The defendant excepted to the claim for constitutional damages. The court held that although damages may in certain circumstances be appropriate relief (as contemplated by section 7(4) of the interim Constitution ${ }^{33}$ ) to vindicate constitutional rights, as pleaded in this case they were excipiable because punitive damages were not considered appropriate relief.

The question of independent causes of action may also arise in circumstances where the legislature has provided legislation to protect rights in the Bill of Rights and possibly even established specialist tribunals to deal with such matters. The obvious example of course is the Commission for Conciliation, Mediation and Arbitration and the Labour Court established by the Labour Relations Act 1995. All of these issues raise difficult questions to which answers have not yet been given.

\section{Conclusion}

The interaction between the common law and the Constitution is fertile ground for academic minds. It seems to me however that the firm normative thrust of the Constitution may well in time prove to be a rich source of principle for the development of the common law. We are fortunate, indeed, to have a common law that is already flexible and familiar with drawing on a wide range of legal sources. That flexibility was criticised by former colleague, Professor DP Visser in his inaugural address at UCT which I referred to earlier, ${ }^{34}$ as being too flexible to meet the basic conceptual requirements of law. In my view, although I agree with his doctrinal analysis of the flexibility of the common law, I disagree with his conclusions. The very flexibility that the common law evinces may well facilitate a rich cross-pollination between it and the Constitution which can only be in the best interests of all South Africans.

3219973 SA 795 (CC); 1997 (7) BCLR 851 (CC).

33 Cf section 38 of the 1996 Constitution.

34 See above notes 7 and 9 at 136-138. 


\section{BIBLIOGRAPHY}

Cameron and Van Zyl Smit Annual Survey

Cameron E and Van Zyl Smit D 1979 Annual Survey of South African Law 511548

Corbett $S A L J$

Corbett MM "Aspects of the Role of Policy in the Evolution of our Common Law" 1987 SALJ 52-69

\section{Fagan Roman-Dutch Law}

Fagan E "Roman-Dutch Law in its South African Historical Context" in Zimmerman R and Visser DP Southern Cross: Civil Law and Common Law in South Africa (Juta Kenwyn 1996)

Hahlo and Kahn Legal System

Hahlo HR and Kahn E The South African Legal System and Its Background (Juta Cape Town 1968)

Visser THRHR

Visser DP "Daedalus in the Supreme Court - the common law today" 1986 THRHR 127.

Zimmerman and Visser Introduction

Zimmerman R and Visser DP "Introduction" to their edited work Southern Cross: Civil Law and Common Law in South Africa (Juta Kenwyn 1996)

\section{Cases}

Administrateur, Natal v Trust Bank van Afrika Bpk 19793 SA 824 (A)

Amod v Multilateral Motor Vehicle Accidents Fund 1998 (10) BCLR 1207 (CC) 
Bester v Commercial Union Versekeringsmaatskappy van Suid Afrika Bpk 19731 SA 768 (A)

Blower v Van Norden 1909 TS 890

Du Plessis and Others v De Klerk and Another 19963 SA 850 (CC); 1996 (5) BCLR 658 (CC)

Du Plessis v Strauss 19882 SA 105 (A)

Fedsure Life Assurance Ltd and Others v Greater Johannesburg Transitional Metropolitcan Council and Others (CCT 7/98 as yet unreported judgment of the Constitutional Court dated 14 October 1998)

Ferreira $v$ Levin NO and Others; Vryenhoek and Others $v$ Powell NO and Others 19961 SA 984 (CC); 1996 (1) BCLR 1 (CC)

Fose v Minister of Safety and Security 19973 SA 795 (CC); 1997 (7) BCLR 851 (CC)

Gardener v Whitaker 19964 SA 337 (CC); 1996 (6) BCLR 775 (CC)

Minister van Polisie v Ewels 19753 SA 590 (A)

National Coalition for Gay and Lesbian Equality and Another v Minister of Justice and Others CCT11/98 an as yet unreported decision dated 9 October 1998

National Media Ltd and Others $v$ Bogoshi (579/96, as yet unreported decision of the Supreme Court of Appeal delivered on 29 September 1998)

Pakendorf en Andere v De Flamingh 19823 SA 146 (A) 
$R v$ Steyn 1954 (1) SA 324 (A)

Rooth $v$ The State (1888) 2 SAR 259

$S \vee J 1998$ (4) BCLR 424 (SCA)

S v Mhlungu 19953 SA 867 (CC); 1995 (7) BCLR 793 (CC)

Shabalala and Others $v$ Attorney-General, Transvaal and Another 19961 SA 725

(CC); 1995 (12) BCLR 1593 (CC)

Tjollo Ateljees (Edms) Bpk v Small 19491 SA 856 (A)

Willis Faber Enthoven (Pty) Ltd v Receiver of Revenue 19924 SA 202 (A)

\section{Legislation}

Black (Urban Areas) Consolidation Act 1945

Black Administration Act 1927

Black Land Act 1913

Divorce Act 1979

Labour Relations Act 1995

Matrimonial Property Act 1984

Matrimonial Property Act 1988 